\title{
RESPON PETANI JAGUNG HIBRIDA TERHADAP KEBIJAKAN HARGA PEMBELIAN PEMERINTAH (HPP) JAGUNG DI KABUPATEN KONAWE
}

\author{
Muhammad Halim ${ }^{1)}$, La Rianda Baka ${ }^{2)}$, Weka Gusmiarty Adbdullah ${ }^{2)}$ \\ ${ }^{1)}$ Mahasiswa Pascasarjana Universitas Halu Oleo \\ ${ }^{1)}$ Email: ihsanpalapa78@gmail.com \\ ${ }^{2)}$ Tenaga Pengajar Pascasarjana Universitas Halu Oleo
}

Naskah diterima: 12 Maret 2019

Naskah direvisi: 21 Maret 2019

Disetujui diterbitkan: 25 April 2019

\begin{abstract}
The development of hybrid corn is a national program in order to achieve the target of corn self-sufficiency. One of the government supports is the issuance of the Government Purchase Price Policy (HPP) through the Minister of Trade Regulation Number 27 / M-DAG/PER / 5/2017 concerning Reference Price for Purchasing Corn. This HPP policy aims to maintain corn availability, price stability and certainty so that the price of corn at the farm level does not fall when the harvest is overflowing. This study was conducted in Konawe District, which is one of the areas of hybrid corn development in Southeast Sulawesi. The aim was to determine the response of hybrid corn farmers to the Government Purchase Price (HPP) policy in Konawe District. The result is the response of hybrid corn farmers to the Government Purchasing Price (HPP) policy in corn in Konawe. Regency is less than or equal to $50 \%$ which has a high response because farmers are still uncertain about the certainty of Bulog's purchase of corn and farmers prefer to sell their crops to the farm collectors who provide convenience to corn farmers include not applying water content requirements and purchases made directly to farmers.
\end{abstract}

Keywords: response, price policy

Intisari: Pengembangan jagung hibrida merupakan program nasional dalam rangka tercapainya target swasembada jagung. Salah satu dukungan pemerintah adalah dikeluarkannya kebijakan Harga Pembelian Pemerintah (HPP) melalui Peraturan Menteri Perdagangan Nomor 27/M-DAG/PER/5/2017 tentang Penetapan Harga Acuan Pembelian Jagung. Kebijakan HPP ini bertujuan untuk menjaga ketersediaan jagung, stabilitas dan kepastian harga sehingga harga jagung di tingkat petani tidak jatuh pada saat panen melimpah. Studi ini dilakukan di Kabupaten Konawe yang merupakan salah satu wilayah pengembangan jagung hibrida di Sulawesi Tenggara. Tujuannya adalah untuk mengetahui respon petani jagung hibrida terhadap kebijakan Harga Pembelian Pemerintah (HPP) di Kabupaten Konawe. Hasilnya Respon petani jagung hibrida terhadap kebijakan Harga Pembelian Pemerintah (HPP) jagung di Kabupaten Konawe adalah kurang dari atau sama dengan 50\% yang mempunyai respon yang tinggi disebabkan karena petani masih ragu dengan kepastian pembelian jagung oleh Bulog dan petani lebih memilih menjual hasil panennya ke pedangan pengumpul yang memberikan kemudahan kepada petani jagung diantaranya tidak menerapkan syarat kadar air dan pembelian dilakukan langsung ke petani.

Kata kunci : respon, kebijakan harga 


\section{PENDAHULUAN}

Komoditas jagung adalah salah satu komoditas strategis yang sangat dibutukan untuk pakan ternak dan pangan. Tahun 2016 tercatat kebutuhan jagung untuk pakan ternak dan pangan mencapai 13,8 juta ton yang terbagi menjadi 8,6 juta ton untuk pakan ternak dan 5,2 juta ton untuk pangan (Kementerian Perindustrian, 2016). Kebutuhan ini harus dipenuhi sehingga melalui Kementerian Pertanian, pemerintah memberikan perhatian yang besar terhadap kebutuhan jagung. Target dari Kementerian Pertanian adalah swasembada jagung dan penghentian import tahun 2017. Upaya yang dilakukan pemerintah untuk mewujudkan swasembada jagung dengan lima strategi yakni dengan peningkatan produksi, perluasan areal tanam, penurunan susut hasil, mempertahankan kualitas hingga memperkuat manajemen kawasan. Kementerian pertanian dalam upaya pengembangan jagung memberikan perhatian khusus karena komoditas jagung mempunyai karateristik yang sangat dipengaruhi oleh lingkungan sehingga hasilnya berfluktuatif. Hal tersebut mempengaruhi permintaan dan penawarannya secara langsung. Apabila penawaran dan permintaan jagung fluktuatif maka akan membentuk harga yang fluktuatif pula (Syamsi, 2012). Sejak tahun 1990 harga jagung di tingkat petani berdasarkan mekanisme pasar sehingga yang terjadi adalah ketika panen harga jagung rendah. Kondisi ini merugikan petani karena petani tidak ada pilihan kecuali menjual hasil panennya dengan harga yang sesuai dengan harga pasar karena harus memenuhi kebutuhan hidup dan mengembalikan modal usahataninya.

Salah satu kebijakan untuk mendukung kegiatan pengembangan jagung adalah dikeluarkannya kebijakan Harga Pembelian Pemerintah (HPP) jagung oleh Menteri Perdagangan melalui Peraturan Menteri Perdagangan Nomor 21/M-DAG/PER/3/2016 dan kemudian tahun 2017 kembali mengeluarkan Peraturan Menteri Perdagangan Nomor 27/M-DAG/PER/5/2017 tentang Penetapan Harga Acuan Pembelian Jagung. HPP ini bertujuan untuk menjaga ketersediaan jagung, stabilitas dan kepastian harga ditingkat petani sehingga harga jagung tidak jatuh pada saat panen. Petani dapat menjual hasilnya kepada pemerintah melalui perum Bulog. Perum Bulog berdasarkan Perpres Nomor 48 Tahun 2016 bertugas untuk menjaga ketersediaan pangan dan stabilitas harga di tingkat konsumen dan produsen. Selanjutnya, berdasarkan Peraturan Menteri Perdagangan Nomor 27/M-DAG/PER/5/ 2017 tentang penetapan harga acuan pembelian jagung di tingkat petani bahwa Perum Badan Urusan Logistik (BULOG) melakukan pembelian jagung produksi dalam negeri dari kelompok tani, gabungan kelompok tani, koperasi petani terutama pada saat panen raya jagung.

Kabupaten Konawe adalah kabupaten yang setiap tahunnya selalu melakukan pertanaman jagung hibrida dan turut menyumbangkan produksi jagung hibrida. Kabupaten Konawe mempunyai potensi lahan untuk pengembangan jagung yaitu pada lahan perkebunan, lahan sawah dengan pergiliran tanam dan lahan bukaan baru yang selama ini tidak dimanfaatkan, oleh karena itu dalam program pengembangan jagung hibrida yang dicanangkan oleh Kementerian Pertanian sejak tahun 2014 maka Kabupaten Konawe menjadi salah satu kabupaten yang sangat potensial untuk pengembangan usahatani jagung. Berdasarkan uraian tersebut maka perlu diketahui seberapa besar respon petani jagung hibrida terhadap kebijakan harga pembelian pemerintah (HPP) jagung di Kabupaten Konawe. Dengan demikian, tujuan dari kajian ini adalah menganalisis respon petani jagung hibrida terhadap kebijakan harga pembelian pemerintah (HPP) jagung di Kabupaten Konawe.

\section{TINJAUAN PUSTAKA}

Respon menurut Kamus Besar Bahasa Indonesia, 1996 adalah tanggapan, reaksi dan jawaban terhadap suatu gejala atau peristiwa yang terjadi. Menurut teori S-O-R bahwa reaksi tertentu akan timbul akibat stimulus tertentu, sehingga seseorang dapat mengharapkan dan memperkirakan pesan yang disampaikan terhadap reaksi komunikan (Effendy O. C, 2003). Menurut Susanto (1988), respon merupakan reaksi, artinya pengiyaan atau penolakan, sikap acuh tak acuh terhadap apa yang disampaikan oleh komunikator dalam pesannya. 
Adi (1994) mengungkapkan bahwa respon pada hakekatnya merupakan tingkah laku balas atau juga sikap yang menjadi tingkah laku balik, yang juga merupakan proses pengorganisasian rangsang dimana rangsangan-rangsangan proksimal diorganisasikan sedemikian rupa sehingga terjadi representasi fenomenal dari rangsangan-rangsangan proksimal (rangsang dalam bentuknya yang sudah diolah oleh penginderaan). Respon dapat juga diartikan hasil dari perilaku stimulus yaitu aktivitas dari orang yang bersangkutan tanpa memandang apakah stimulus tersebut dapat diidentifikasikan atau tidak dapat diamati. Respon akan terkait dengan stimulus jika stimulus terjadi maka suatu respon akan mengikuti (Gibson et al, 1988).

Menurut Rusmialdi (1997), respon adalah segala sesuatu yang dilakukan oleh individu akibat merasakan rangsangan. Respon dapat juga diartikan sebagai wujud reaksi (tanggapan) dari interpretasi seseorang mengenai rangsangan yang datang pada dirinya, dalam hal ini indera seseorang. Menurut Rakhmat J, (1999), respon terbagi atas tiga bagian, yaitu: respon kognitif, yaitu: 1) respon yang timbul setelah adanya pemahaman terhadap sesuatu yang terkait dengan informasi atau pengetahuan, terjadi bila ada perubahan pada apa yang diketahui atau dipersepsi khalayak; 2) respon afektif, yaitu respon yang timbul karena adanya perubahan perasaan terhadap sesuatu yang terkait dengan emosi, sikap dan nilai, timbul bila ada perubahan pada apa yang dirasakan, disenangi atau dibenci khalayak; 3) respon konatif, yaitu respon yang berupa tindakan, kegiatan atau kebiasaan yang terkait dengan perilaku nyata. Merujuk pada perilaku nyata yang dapat diamati yang meliputi pola pola tindakan, kegiatan atau kebiasaan perilaku.

\section{METODE KAJIAN}

Studi dilakukan di Kabupaten Konawe Provinsi Sulawesi Tenggara pada bulan Januari sampai dengan Agustus 2018. Lokasi studi ditentukan secara purposive (sengaja) dengan alasan bahwa Kabupaten Konawe adalah salah satu kabupaten yang melakukan pengembangan jagung hibrida dan telah diberlakukan kebijakan harga pembelian pemerintah. Populasi adalah petani jagung hibrida yang berjumlah 7.276 petani. Penentuan sampel dilakukan dengan cara simple random sampling atau secara acak sederhana. Jumlah sampel ditetapkan dengan menggunakan rumus Slovin dalam Dewanti dan Sihombing (2012) sehingga jumlah sampel studi ini sebanyak 99 petani jagung hibrida.

Variabel respon yang diamati meliputi: 1) respon kognitif diamati dari pengetahuan dan pemahaman petani tentang kebijakan HPP; 2) respon afektif diketahui dari perasaan petani berupa ketertarikan, suka atau tidak dan baik dan buruknya kebijakan HPP; 3) respon konatif dapat dilihat dari tindakan petani yang berupa perluasan areal tanam, peningkatan produktivitas, peningkatan kualitas jagung dan penjualan jagung ke Bulog. Untuk mengukur respon petani digunakan skala likert, yaitu: . sangat setuju (SS) dengan skor 5, setuju (S) dengan skor 4, netral (N) dengan skor 3, tidak setuju (TS) dengan skor 2 dan sangat tidak setuju (STS) dengan skor 1 (Siregar S, 2012). Kategori respon dikelompokkan menjadi 3, yaitu: 1) respon rendah jika jawaban petani mempunyai interval skor 0-55; b) respon sedang jika jawaban petani mempunyai interval skor 56-110, c) respon tinggi jika jawaban petani mempunyai interval skor 111-165.

Untuk mengetahui respon petani jagung hibrida terhadap kebijakan Harga Pembelian Pemerintah (HPP) jagung digunakan uji proporsional dengan hipotesis sebagai berikut:

$$
\begin{aligned}
& \text { Ho }: \mathrm{P} \leq 50 \% \\
& \mathrm{H}_{1}: \mathrm{P}>50 \%
\end{aligned}
$$

Ho : diduga kurang dari atau sama dengan 50 persen petani mempunyai repon yang tinggi terhadap kebijakan Harga Pembelian Pemerintah (HPP) jagung.

$\mathrm{H}_{1} \quad$ : diduga lebih dari 50 persen petani mempunyai respon yang tinggi terhadap kebijakan Harga Pembelian Pemerintah (HPP) jagung.

Untuk menguji hipotesis digunakan tingkat signifikansi $(\alpha)=0,05$ dan $\mathrm{n}=99$ dengan rumus: 


$$
\text { Z hit }=\frac{x / n-P o}{\sqrt{\frac{P o(1-P o)}{n}}}
$$

Keterangan:

$\mathrm{x} \quad=$ Jumlah petani jagung hibrida yang mempunyai repon yang tinggi di Kabupaten Konawe.

$\mathrm{n}=$ Jumlah sampel petani jagung hibrida.

Po $=$ proporsi populasi $(50 \%)$

Kriteria pengambilan kesimpulan:

- Jika Z-hitung > Z-tabel; maka $\mathrm{H}_{0}$ ditolak dan $\mathrm{H}_{1}$ diterima,

- Z-hitung < Z-tabel; Ho diterima dan $\mathrm{H}_{1}$ ditolak (Suryabrata, Sumadi, 2004).

\section{HASIL DAN PEMBAHASAN}

\subsection{Respon Petani Jagung Hibrida terhadap kebijakan Harga Pembelian Pemerintah (HPP)}

Dalam studi ini respon petani dikelompokkan menjadi tiga aspek, yaitu: respon kognitif, respon afektif, dan respon konatif. Hasil kajian diuraikan sebagai berikut:

1. Respon Kognitif

Tingkat respon petani jagung hibrida terhadap kebijakan Harga Pembelian Pemerintah (HPP) berdasarkan aspek kognitif dapat dilihat pada Tabel 1.

Tabel 1. Respon Kognitif Petani Jagung Hibrida terhadap Kebijakan Harga Pembelian Pemerintah

\begin{tabular}{clcc}
\hline No & \multicolumn{1}{c}{ Tingkat Respon } & $\begin{array}{c}\text { Jumlah Jiwa } \\
\text { (Orang) }\end{array}$ & $\begin{array}{c}\text { Persentase } \\
(\%)\end{array}$ \\
\hline 1 & Rendah $(0-16,7)$ & 5 & 5,05 \\
2 & Sedang $(16,8-33,4)$ & 20 & 20,20 \\
3 & Tinggi $(33,5-50)$ & 74 & 74,75 \\
\hline \multicolumn{2}{l}{ Jumlah } & 99 & 100,00 \\
\hline
\end{tabular}

Tabel 1 menunjukkan bahwa dari aspek kognitif, sebagian besar ( 74 orang atau 74,75 persen) petani responden mempunyai skor tinggi, yang berarti bahwa sebagian besar petani mempunyai respon positif atau respon yang baik. Dengan demikian, hal ini dapat menggambarkan bahwa dari aspek kognitif, sebagian besar petani telah mempunyai pengetahuan dan pemahaman tentang maksud dan tujuan dari kebijakan HPP, yaitu bahwa Bulog akan membeli jagung dengan syarat-syarat yang harus dipenuhi yakni syarat kadar air 15 persen dengan kualitas yang baik dan pembelian jagung di gudang Bulog.

\section{Respon Afektif}

Tingkat respon petani jagung hibrida terhadap kebijakan Harga Pembelian Pemerintah (HPP) berdasarkan aspek afektif dapat dilihat pada Tabel 2. Tabel 2 menunjukkan bahwa dari aspek afektif, sebagian besar (73 orang atau 73,74 persen) petani responden mempunyai skor tinggi, yang berarti bahwa sebagian besar petani mempunyai respon positif atau respon yang baik. Dengan demikian, dapat menggambarkan bahwa dari aspek afektif, sebagian besar petani jagung hibrida tertarik dan menyukai kebijakan HPP karena kebijakan ini dianggap sangat membantu petani dalam penjualan hasil panen dengan harga yang memadai. 
Tabel 2. Respon Afektif Petani Jagung Hibrida terhadap Kebijakan Harga Pembelian Pemerintah (HPP)

\begin{tabular}{clcc}
\hline No & \multicolumn{1}{c}{ Tingkat Respon } & $\begin{array}{c}\text { Jumlah Jiwa } \\
\text { (Orang) }\end{array}$ & $\begin{array}{c}\text { Persentase } \\
(\%)\end{array}$ \\
\hline 1 & Rendah $(0-18,3)$ & 5 & 5,05 \\
2 & Sedang $(18,4-36,6)$ & 21 & 21,21 \\
3 & Tinggi $(36,7-55)$ & 73 & 73,74 \\
\hline \multicolumn{2}{l}{ Jumlah } & 99 & 100,00 \\
\hline
\end{tabular}

\section{Respon Konatif}

Tingkat respon petani jagung hibrida terhadap kebijakan Harga Pembelian Pemerintah (HPP) berdasarkan aspek konatif dapat dilihat pada Tabel 3.

Tabel 3. Respon Konatif Petani Jagung Hibrida terhadap Kebijakan Harga Pembelian Pemerintah (HPP)

\begin{tabular}{clcc}
\hline No & \multicolumn{1}{c}{ Tingkat Respon } & $\begin{array}{c}\text { Jumlah Jiwa } \\
\text { (Orang) }\end{array}$ & $\begin{array}{c}\text { Persentase } \\
(\%)\end{array}$ \\
\hline 1 & Rendah (0-20) & 2 & 2,02 \\
2 & Sedang (21-40) & 60 & 60,61 \\
3 & Tinggi (41-60) & 37 & 37,37 \\
\hline \multicolumn{2}{l}{ Jumlah } & 99 & 100,00 \\
\hline
\end{tabular}

Tabel 3 menunjukkan bahwa dari aspek konatif, sebagian besar (60 orang atau 60,61 persen) petani responden mempunyai skor sedang, yang menggambarkan bahwa sebagian besar petani hanya merespon sedang saja atau ragu-ragu untuk melakukan tindakan dan perilaku nyata secara maksimal. Keraguan yang paling dirasakan petani adalah terkait dengan kepastian pembelian yang akan dilakukan oleh Bulog sehingga petani cenderung untuk menjual hasil panen jagung hibrida kepada pedagang pengumpul.

Selanjutnya, diuraikan rata-rata tingkat respon petani jagung hibrida terhadap kebijakan Harga Pembelian Pemerintah (HPP). Hasil kajian rata-rata tingkat respon petani jagung hibrida terhadap kebijakan Harga Pembelian Pemerintah (HPP) dapat dilihat pada Tabel 4.

Tabel 4. Rata-rata Total Respon Petani Jagung Hibrida terhadap Kebijakan Harga Pembelian Pemerintah (HPP)

\begin{tabular}{clcc}
\hline No & \multicolumn{1}{c}{ Tingkat Respon } & $\begin{array}{c}\text { Jumlah Jiwa } \\
\text { (Orang) }\end{array}$ & $\begin{array}{c}\text { Persentase } \\
(\%)\end{array}$ \\
\hline 1 & Rendah (0-55) & 6 & 6,06 \\
2 & Sedang (56-110) & 54 & 54,55 \\
3 & Tinggi (111-165) & 39 & 39,39 \\
\hline \multicolumn{2}{l}{ Jumlah } & 99 & 100,00 \\
\hline
\end{tabular}

Tabel 4 menunjukkan bahwa sebagian besar petani jagung hibrida mempunyai respon yang sedang, yakni 54 orang (54,55 persen) terhadap kebijakan Harga Pembelian Pemerintah (HPP) sedangkan respon yang tinggi berjumlah 39 orang atau 39,39\%.

Dengan menggunakan analisis uji $\mathrm{Z}$ maka didapatkan nilai $\mathrm{Z}$ hitung $=-2,121<\mathrm{Z}$ tabel $=1,64$ yang berarti $\mathrm{H}_{1}$ ditolak, dan $\mathrm{H}_{\mathrm{O}}$ diterima, artinya bahwa kurang dari atau sama dengan 50 persen petani jagung hibrida mempunyai respon yang tinggi terhadap kebijakan Harga Pembelian Pemerintah (HPP) jagung di Kabupaten Konawe. Hal ini menunjukkan bahwa sebaran petani yang mempunyai respon tinggi masih kurang dari atau sama dengan 50\% yang berarti bahwa kebijakan HPP di Kabupaten Konawe belum seluruhnya mendapatkan respon yang baik atau tinggi. Hal ini disebabkan oleh 
keraguan petani terhadap kepastian pembelian jagung oleh Bulog dan syarat yang diterapkan oleh Bulog sangat ketat terkait kadar air dan kualitas pembelian jagung hibrida sehingga petani memilih menjual ke pedagang pengumpul yang memberikan beberapa kemudahan, di antaranya adalah pedagang pengumpul langsung mendatangi petani untuk membeli jagung sehingga petani tidak perlu mengeluarkan biaya transportansi ke gudang, pembelian jagung petani tidak dipatok dengan kadar air sebesar 15 persen, yang penting jagung tersebut kering, dan ada juga pedagang pengumpul yang memberikan modal atau pinjaman dana terlebih dahulu kepada petani dengan perjanjian hasil panen akan dijual ke pedagang yang memberi pinjaman dana.

\section{KESIMPULAN DAN SARAN}

Hasil kajian menyimpulkan bahwa: 1) respon petani jagung hibrida terhadap kebijakan Harga Pembelian Pemerintah (HPP) jagung di Kabupaten Konawe adalah kurang dari atau sama dengan 50\% yang mempunyai respon tinggi; 2) Masih kurangnya petani yang merespon tinggi kebijakan HPP jagung disebabkan karena petani lebih memilih menjual ke pedagang pengumpul yang memberikan beberapa kemudahan, yaitu: pedagang pengumpul langsung mendatangi petani untuk membeli jagung sehingga petani tidak perlu mengeluarkan biaya transportasi ke gudang; dan pedagang pengumpul tidak mensyaratkan kadar air jagung sebesar 15 persen untuk pembelian jagung, yang penting kering.

Berdasarkan hal tersebut maka dapat disarankan: 1) bagi petani jagung hibrida agar selalu menjaga dan meningkatkan kualitas hasil panen jagung karena standar pembelian jagung oleh Bulog adalah kualitas baik dan kadar air sebesar 15 persen; 2) Bagi pemerintah, pelaksanaan kebijakan Harga Pembelian Pemerintah (HPP) jagung di Kabupaten Konawe perlu dievaluasi karena petani jagung hibrida yang memiliki respon yang tinggi terhadap HPP masih kurang dari atau sama dengan 50 persen; 3) bagi peneliti selanjutnya, diharapkan dapat menjadi acuan dalam mengkaji respon petani terhadap kebijakan-kebijakan yang dikeluarkan pemerintah terkait pengembangan pertanian.

\section{DAFTAR PUSTAKA}

Adi, I.R. 1994. Psikologi Pekerjaan Sosial dan Ilmu Kesejahteraan Sosial (Dasar-dasar Pemikiran). Raja Grafindo Persada. Jakarta.

Effendi, O.U. 2003. Ilmu Komunikasi. Teori dan Praktik. PT. Rosda Karya. Bandung.

Gerungan, W. A. 1978. Psikologi Sosial. Eresco. Bandung.

Gibson, J; L. Donnely; J.H. Ivancevich; M. John dan J. Wahid. 1988. Organisasi dan Manajemen: Perilaku, Struktur, Proses. Erlangga, Jakarta.

Mubyarto. 1989. Pengantar Ekonomi Pertanian. LP3ES. Jakarta.

Mardikanto, T. 2010. Komunikasi Pembangunan. Universitas Sebelas Maret Press. Surakarta.

Novia, R,A, 2011. Respon Petani Terhadap Kegiatan Sekolah Lapangan Pengelolaan Tanaman Terpadu (SLPTT) di Kecamatan Ajibarang Kabupaten Banyumas. Fakultas Pertanian Universitas Brawijaya. Malang.

Rahmad, J. 1999. Psikologi Komunikasi. PT Remaja Rosda Karya. Bandung.

Rusmialdi, R. 1997. Tanggapan Petani Terhadap Iuran P3A di Kabupaten Lampung Tengah Propinsi Lampung (Antisipasi Terhadap Pengembangan P3A Mandiri). Jurnal Sosial Ekonomika. Universitas Lampung. Bandar Lampung.

Susanto, A. 1988. Komunikasi Dalam Teori dan Praktek. Jilid Satu. Bina Cipta. Jakarta.

Sarwono, S. W. 2005. Teori-teori Psikologi Sosial. PT Raja Grafindo Persada. Jakarta.

Suryabrata, S. 2004. Metodologi Penelitian. PT Raja Grafindo Persada. Jakarta.

Wijayanti, A. dkk. 2015. Respon Petani Terhadap Inovasi Budidaya Dan Pemanfaatan Sorgum Di Kecamatan Srandakan Kabupaten Bantul. 